\title{
Mikrobaközösségek metabolikus aktivitása és 16S rRNS gén alapú filogenetikai diverzitása kukorica monokultúra rizoszféra-talajban
}

\author{
UJVÁRI Gergely ${ }^{1}$, BorSODI Andrea ${ }^{1}$, AsZALÓs Júlia Margit ${ }^{1}$, MEGYES Melinda ${ }^{1}$, \\ MuCSI Márton ${ }^{2}$, SzABÓ Attila ${ }^{1}$, MÁRIALIGETI Károly ${ }^{1}$ \\ ${ }^{1}$ ELTE Eötvös Loránd Tudományegyetem, Mikrobiológiai Tanszék; Budapest \\ ${ }^{2}$ MTA, ATK, Talajtani és Agrokémiai Intézet; Budapest \\ (Beérkezett: 2018. október 10.; elfogadva: 2018. november 22.)
}

\section{Bevezetés}

Talán túlzás nélkül állíthatjuk, hogy a talajban és a vizekben a mikroorganizmusok sokasága, tetemes biomasszájának és anyagcsere útjaik sokféleségének köszönhetően meghatározó jelentőségü az emberiség számára. A talaj biomasszáját JENKINSON (1977) egy tủ fokához hasonlította, melyen a talajba kerülő összes szerves anyagnak át kell jutnia. A talajt benépesítő mikrobáknak alapvető szerepük van a talajszerkezet alakításában, a különböző szerves anyagok átalakításában és lebontásában, a toxinok eliminációjában, továbbá az elemek biogeokémiai körforgalmának fenntartásában. A mikrobaközösségek ily módon "kollektív katalizátorai" a talajban végbemenő biokémiai folyamatok összességének (GARBEVA et al., 2004; HAYAT et al., 2010).

A mezőgazdasági művelés (talajmunkák, öntözés, a talaj termékenységét fokozó eljárások, peszticidek, vetésforgók és monokultúrák alkalmazása) okozta környezeti változások befolyásolják a talaj mikrobaközösségek aktivitását és diverzitását (GARBEVA et al., 2004), ugyanakkor a mikrobaközösségek egyes tagjai, illetve az egész közösség sokszínüsége is hatással van a növénytermesztés hatékonyságára (ISHAQ et al., 2017). A fenntartható mezőgazdaság a XXI. században az agrárkutatások kiemelt jelentőségủ kutatási területe a növekvő emberi populáció élelmiszerigénye, a klímaváltozás és a mütrágyázás okozta vízszennyezés miatt.

A témával foglalkozó legtöbb kutatás arra mutatott rá, hogy a monokultúrák és vetésforgók talajában mérhető mikrobiális diverzitás alacsonyabb volt a természetes társulásokénál (VAN ElSAS et al., 2002; GARBEVA et al., 2003; GARBEVA et al., 2004). Ennek egyik oka az lehet, hogy a természetes társulásokban a növények és a hozzájuk kapcsolódó mikroorganizmusok koevolúciójával ellentétben a termesztett fajták szelekciója által okozott genetikai diverzitáscsökkenés hatással van a mikrobaközösségek diverzitás mintázatára is (PÉREZ-JARAMILLO et al., 2015).

A mezőgazdasági művelés a talaj mikrobaközösségek metabolikus aktivitására is erős befolyást gyakorol; egyes kutatási eredmények alapján a felhagyott mezőgazdasági területek mikrobiális aktivitása még 20 év szukcesszió után sem közelített a természetes talajokban mérhető értékekhez (PASCUAL et al., 2000).

Postai cím: BORSODI Andrea; ELTE Eötvös Loránd Tudományegyetem, Mikrobiológiai Tanszék; 1117 Budapest, Pázmány Péter sétány 1/C

E-mail cím: borsodi.andrea@ttk.elte.hu 
Fontos azonban szem előtt tartani, hogy a rizoszférában mérhető enzimaktivitás és a bakteriális diverzitás nem korrelál egymással (LING et al., 2014).

A rizoszférában, mint speciális környezetben, a növényi gyökerek anyagleadása; az exudátumok mennyisége, minősége, hozzáférhetősége fontos alakítója a gyökeret körülvevő talaj mikrobaközösségeinek (BAUDOIN et al., 2003). Durva becsléssel a fotoszintetikus úton megkötött C-molekulák 10-44\%-a a gyökérzeten keresztül távozik a növényből, ami növeli a talajban lévő mikrobiális biomassza mennyiségét és aktivitását (BERG és SMALLA, 2009). Az exudátumok révén a mikrobaközösségek (Biolog ${ }^{\circledR} \mathrm{GN} 2$ lemezen mért) metabolikus ujjlenyomata jelentősen megváltozhat, és a sejtek denzitásának növekedése miatt a quorum sensing folyamatok is módosulhatnak (BAUDOIN et al., 2003).

A kukorica által leadott rizoexudátumok megközelítőleg 65\%-ban cukrokból, 33\%-ban szerves savakból és 2\%-ban aminosavakból állnak (AIRA et al., 2010). A pontos összetétel fajtánként, fenotípusonként változhat. A ma ismert, termesztett kukorica (Zea mays ssp. mays) rizoszférájának metabolikus aktivitását KANDELER és munkatársai (2002) tanulmányozták. A kukorica rizoszféra-talaj baktériumközösségeinek genetikai diverzitásáról, a jellemző csoportok feltárásáról már rendelkezésre állnak tanulmányok (PEIFFER et al., 2013; GARCÍA-SALAMANCA et al., 2013; Li et al., 2014/I; LI et al., 2014/II; JoHNSTON-MONJE és RAIZADA, 2011), de ezek igen változatos eredményekre vezettek a fentebb már említett környezeti és művelési sokféleség miatt.

Mikrobiális légzési aktivitásméréssel megállapították, hogy bár a különböző művelésű talajokból származó közösségek hasonlóan reagáltak a kiszáradás-nedvesedés stressz hatására, az organikus müvelésủ talajokban mérhető respirációs aktivitás (egységnyi biomasszára vetítve) többszöröse volt a szervetlen trágyázású talajénak. Újranedvesedés után a talaj felszínközeli rétegében jóval gyorsabb és nagyobb léptékủ változások következtek be a mélyebb talajrétegekhez képest, vagyis az itt található mikroorganizmusok jobban adaptálódtak a hasonló ciklusokhoz (LUNDQUIST et al., 1999).

A bakteriális diverzitás vizsgálata során ISHAQ és munkatársai (2017) steril mikrokozmoszokat oltottak be különböző helyszínekröl, különböző müvelési módokból származó talajmintákkal. Illumina MiSeq platformon végzett 16S rRNS gén szekvenálásuk eredményei alapján arra a következtetésre jutottak, hogy a művelési mód hatással volt a bakteriális diverzitásra: az organikus trágyázású inokulummal oltott talajok fajgazdagabbak, diverzebbek voltak (Shannon-Weaver index).

A svájci DOK tartamkísérletben a Biolog ${ }^{\mathrm{TM}}$ EcoPlates szubsztrát-hasznosítási mintázat alapján a termékenységet fokozó eljárások alkalmazása nélkül művelt talajok egyértelmüen elkülöníthetők voltak a többitől (WIDMER et al., 2006). Ugyanezen tartamkísérletben a funkcionális diverzitás és a metabolikus aktivitás varianciáját 27,9\%-ban a gazdálkodás módja, 8,6\%-ban pedig a termesztett növény típusa (őszi búza / lóherés kaszáló) magyarázta, míg a T-RFLP alapú genetikai diverzitásméréssel ezek az értékek 35,6\% és 7,4\% voltak (HARTMANN et al., 2015).

Jelen munka a "Talajbiom kutató transzdiszciplináris kiválósági központ létrehozása a fenntartható talajerőforrás biztosítása érdekében" címủ projekt 
részeként végzett előkísérlet volt, melynek során egy hosszú távú mezőgazdasági müvelésbe vont (trágyázás nélküli kukorica monokultúra) rizoszféra-talaj és egy természetközeli állapotú löszpusztagyep talajában előforduló mikrobaközösségek taxonómiai sokféleségét és anyagcsere aktivitását elemeztük és hasonlítottuk össze egymással különböző módszerekkel.

\section{Anyagok és módszertan}

A Martonvásár határában felállított tartamkísérlet az MTA Agrártudományi Kutatóközpontjához (ATK) tartozik. A területen löszös alapkőzeten kialakult, erdös sztyeppből eredő, igen heterogén tulajdonságokkal rendelkező talaj található. Foszfor ellátása gyér, míg kálium utánpótlása bőséges (BERZSENYI, 2010). Az aktivitás- és diverzitásmérésekbe bevont, trágyázatlan kukorica monokultúra parcella az 1961 óta azonos rend szerint müvelt szabadföldi kísérlet területén található. A parcella permetezése Lumax ${ }^{\circledR}\left(51 \mathrm{ha}^{-1}\right)$, Monsoon ${ }^{\circledR}$ Active $\left(21 \mathrm{ha}^{-1}\right)$ és $\operatorname{Mospilan}^{\circledR}\left(0,15 \mathrm{~kg} \mathrm{ha}^{-1}\right)$ növényvédő szerekkel történt.

Vizsgálatainkhoz kontroll területként a Bicske határában található Natura2000 védett területet jelöltük ki, mivel itt találtunk legközelebb természetközeli állapotú, löszös talajjal rendelkező gyepet a Szent László-patak vízgyüjtő területén. A terület a '90-es évekig extenzív marhalegelőként volt nyilvántartva. $7 \mathrm{~m} * 7$ m nagyságú kvadrátban az április végén készült felvételezés alapján 45 növényfajt azonosítottunk. A gyep borítása $100 \%$; a gyep magassága $40 \mathrm{~cm}$ volt, de egyes kiemelkedő kétsziküek $80 \mathrm{~cm}$-es magasságot is elértek. A terület uralkodó füve a barázdált csenkesz (Festuca rupicola) és a tollas szálkaperje (Brachypodium pinnatum), mindkettő 35\%-os borítottsággal (KALAPOS T. szóbeli közlése alapján).

Mindkét terület talaja feozjomként klasszifikálható, ám a löszös $C$ réteg fölött 5-10 cm vastagságban homok volt (SZALAI Z. szóbeli közlése alapján).

\section{1. táblázat}

A vizsgálatba vont talajminták jelölése, származása.

(Helyszín: $\mathrm{M} \rightarrow$ Martonvásár, $\mathrm{B} \rightarrow$ Bicske)

\begin{tabular}{|c|c|c|c|c|}
\hline $\begin{array}{c}\text { (1) Minta } \\
\text { jelölése }\end{array}$ & $\begin{array}{c}\text { (2) Múvelés } \\
\text { módja }\end{array}$ & (3) Helyszín & (4) Mélység [cm] & $\begin{array}{c}\text { (5) Mintavételi időpont } \\
\text { (2017) }\end{array}$ \\
\hline A_A4 & Term. (a) & B & $0-10$ & Április (a) \\
\hline A_C4 & Term. (a) & B & $50-60$ & Április (a) \\
\hline K_A4 & Kukorica (b) & M & $0-10$ & Április (a) \\
\hline K_A6 & Kukorica (b) & M & $0-10$ & Június (b) \\
\hline K_C6 & Kukorica (b) & M & $60-70$ & Június (b) \\
\hline K_A7 & Kukorica (b) & M & $0-10$ & Július (c) \\
\hline
\end{tabular}

A talajmintákat 2017-ben gyűjtöttük (1. táblázat). A mintavételekhez 95\%-os etanollal sterilizált Pürckhauer-fúrót használtunk. A talajmintákat négy órán belül a 
laboratóriumba szállítottuk, ahol a DNS-kivonás elött a nagyobb talajrögök belsejéből különítettünk el steril Eppendorf csövekbe 1-1 g-nyi vizsgálati mennyiségeket.

Az NGS (új generációs szekvenálás) technikával vizsgált és az aktivitásmérésbe vont talajmintákat a mintavételtől a 3 napon belül elvégzett DNSkivonásig, illetve a MicroResp mérésig $4{ }^{\circ} \mathrm{C}$-os hütőben tároltuk.

A közösségi DNS-izolálást MO BIO PowerSoil DNA Isolation Kittel (MO BIO Laboratories Inc., Carlsbad, USA) végeztük 0,25 g minta felhasználásával, a gyártó által ajánlott protokollt követve.

A diverzitás elemzésbe vont mintákat a szekvenálást végző szervezet (Genomics Core, Research Technology Support Facility, Michigan State University, Trowbridge, USA) protokollja alapján dolgoztuk fel. Egy lépésben PCR (polimeráz láncreakció) amplifikációt végeztünk a $16 \mathrm{~S}$ rRNS géne egy részletén a CS1-TS-B341F (B341F: CCT ACG GGA GGC AGC AG) és a CS2-TS-805NR (805NR: GGA CTA CHV GGG TWT CTA AT) primerekkel $25 \mu$ l végtérfogatban. A PCR premix mintánként $5 \mu \mathrm{l} \mathrm{HF} \mathrm{puffert,} 5 \mu \mathrm{l}$ dNTP-t, $11,75 \mu \mathrm{l}$ vizet, $0,625 \mu \mathrm{l}$ forward $(0,66 \mu \mathrm{M})$ és $0,625 \mu \mathrm{l}$ reverse $(0,66 \mu \mathrm{M})$ primert, $0,5 \mu \mathrm{l}$ BSA-t (szarvasmarha szérum albumin), $0,25 \mu \mathrm{l}$ Phusion ${ }^{\circledR} \mathrm{HF}$ polimerázt $(0,5 \mathrm{U})$ és $1,25 \mu \mathrm{l}$ templátot tartalmazott. Az amplifikáció során 5 perces denaturációt végeztünk 98 ${ }^{\circ} \mathrm{C}$-on, majd 25 cikluson keresztül $95{ }^{\circ} \mathrm{C}$-on $40 \mathrm{mp}$ denaturációs, $55{ }^{\circ} \mathrm{C}$-on $30 \mathrm{mp}$ annelációs és $72{ }^{\circ} \mathrm{C}$-on 1 perc elongációs időt alkalmaztunk, végül 10 perc elongációval zártuk a folyamatot $72{ }^{\circ} \mathrm{C}$-on, a kész termékeket pedig $4{ }^{\circ} \mathrm{C}$-ra hütöttük le.

A PCR termékek meglétét és minőségét minden esetben $1 \%$-os agaróz gélben történő futtatással $(100 \mathrm{~V} ; 500 \mathrm{~mA} ; 20$ perc $)$ ellenőriztük. Az ellenőrző elektroforézishez minden csőből $5 \mu l$ terméket használtunk fel. A szekvenáláshoz Illumina MiSeq platformot (Illumina Inc., San Diego, USA) vettünk igénybe.

A metabolikus aktivitás-mintázatot szubsztrát-indukált respiráció alapján mértük a MicroResp ${ }^{\mathrm{TM}}$ rendszerrel (Macaulay Scientific Consulting Ltd., Aberdeen, UK). A szubsztrátok vízben jól oldódó cukrok, aminosavak vagy szerves savak voltak, amelyek a gyökér exudátumokban gyakran előfordulnak (MUCSI et al., 2017; SzILI-KovÁCS et al., 2017). E módszerrel a talajhoz hozzáadott szubsztrát hatására a mikrobiális légzés során felszabaduló $\mathrm{CO}_{2}$-t mértük fotometriásan. A két, egymással szemben elhelyezkedő, 96-üregü mikrotiter lemez közül az alsó mélyüregüben volt a talaj a hozzáadott szubsztrátokkal (23 különböző szubsztrát + desztillált víz; 4 ismétlésben). A felső detektor lemez 1\%-os, nagy tisztaságú Oxoid $^{\mathrm{TM}}$ Purified Agart (Thermo Fisher Scientific Inc., Waltham, USA), KCl-t, $\mathrm{Na}\left(\mathrm{CO}_{3}\right)_{2}$-ot és krezolvörös indikátort tartalmazott. A detektor lemezek abszorbanciáját a szubsztrátok hozzáadása előtt fotometriásan lemértük $570 \mathrm{~nm}$ hullámhosszon, majd a szubsztrátok hozzáadása után a lemezeket lezártuk, $25^{\circ} \mathrm{C}$-os inkubátorba helyeztük, és 5 óra múlva ismét mértük a detektorlemezek abszorbanciáját (CAMPBELL et al., 2003; SZILI-KovÁCS, 2004).

A mérés során a gyártói utasításoknak megfelelően jártunk el. Az alkalmazott szubsztrát oldatok: D-galaktóz $\left(80 \mathrm{~g}^{-1}\right)$, trehalóz $\left(80 \mathrm{~g} \mathrm{l}^{-1}\right)$, L-arabinóz $\left(80 \mathrm{~g} \mathrm{l}^{-1}\right)$, D-glükóz $\left(80 \mathrm{~g} \mathrm{l}^{-1}\right)$, D-fruktóz $\left(80 \mathrm{~g} \mathrm{l}^{-1}\right)$, citrát $\left(40 \mathrm{~g} \mathrm{l}^{-1}\right)$, DL-malát $\left(40 \mathrm{~g} \mathrm{l}^{-1}\right)$, 
szukcinát $\left(40 \mathrm{~g} \mathrm{l}^{-1}\right)$, L-alanin $\left(40 \mathrm{~g} \mathrm{l}^{-1}\right)$, L-lizin $\left(40 \mathrm{~g} \mathrm{l}^{-1}\right)$, L-glutamin $\left(20 \mathrm{~g} \mathrm{l}^{-1}\right)$, L-arginin $\left(12 \mathrm{~g} \mathrm{l}^{-1}\right)$, 3,4-dihidroxi-benzoát $\left(12 \mathrm{~g} \mathrm{l}^{-1}\right)$, L-glutamát $\left(12 \mathrm{~g} \mathrm{l}^{-1}\right)$, myo-inozitol (80 $\left.\mathrm{g} \mathrm{l}^{-1}\right)$, D-xilóz (80 $\left.\mathrm{g} \mathrm{l}^{-1}\right)$, D-mannitol (80 $\left.\mathrm{g} \mathrm{l}^{-1}\right)$, D-mannóz $\left(80 \mathrm{~g} \mathrm{l}^{-1}\right)$, D-szorbitol $\left(80 \mathrm{~g} \mathrm{l}^{-1}\right)$, L-ramnóz $\left(80 \mathrm{~g} \mathrm{l}^{-1}\right)$, L-aszparagin $\left(20 \mathrm{~g} \mathrm{l}^{-1}\right)$, kálium-glükonát $\left(40 \mathrm{~g} \mathrm{l}^{-1}\right)$, L-szerin $\left(20 \mathrm{~g} \mathrm{l}^{-1}\right)$, valamint desztillált víz kontrollként.

Munkánk során az NMDS (Non-metric Multidimensional Scaling) relációkat, a SIMPER-tesztet és az UPGMA (Unweighted Pair Group Method with Arithmetic Mean) módszerrel leírható hasonlóságot Past3 3.20 (HAMMER et al., 2001) szoftverrel elemeztük. Az NGS adatok feldolgozása során a SILVA 4.20 adatbázisra támaszkodtunk. Az NGS adataiból az OTU-abundanciát (Operational Taxonomic Unit) szemléltető hálózatot Cytoscape 3.6.0 (The Cytoscape Consortium, New York, USA) (SHANNON et al., 2003) programmal rajzoltuk.

\section{Eredmények és megvitatásuk}

Az NGS szekvenálás adatai alapján a mélyebb és a felszínközeli talajrétegek, illetve a természetes és a müvelésbe vont talajok elválását, továbbá a szakirodalmi források által mezőgazdasági talajokra, kukorica rizoszférára jellemzőnek talált baktérium taxonok megjelenését valószínüsítettük.

Az NGS vizsgálatba vont 6 talajmintában összesen 9059 OTU-t (Operational Taxonomic Unit), ezeken belül 1711 taxont sikerült azonosítanunk. Mintánként 29117-56488 szekvenciát olvastunk le; a mintánként 29117 szekvenciára szükített adatbázis alapján számított Chao1 OTU-szám becsléseket és inverz Simpson indexeket a 2. táblázat tartalmazza. Ez alapján a kukorica monokultúra talaj szántott rétegében tavasszal (K_A4) mérhető inverz Simpson diverzitás a fiatal növények alatt (K_A6) megnőtt, majd később (K_A7) jelentősen csökkent. A kukorica alatti talaj $\mathrm{C}$ rétegében (K_C6) a bakteriális diverzitás nem érte el a felszínen mérhető változatosságot. $\mathrm{Az}$ inverz Simpson diverzitás érték a bicskei kontroll talaj $\mathrm{A}$ rétegében (A_A4) elmaradt a müvelt talajtól, ugyanakkor a C rétegben (A_C4) nem tért el jelentősen.

\section{2. táblázat}

Az NGS alapján számított Chao1 OTU-szám becslés és inverz Simpson diverzitás-index értékei

\begin{tabular}{|l|r|r|r|r|}
\hline \multirow{2}{*}{ (1) Minta } & \multicolumn{2}{|c|}{ (2) Chao1 } & \multicolumn{2}{c|}{ (3) Inverz Simpson } \\
\cline { 2 - 5 } & (4) Átlag & (5) Szórás & (4) Átlag & (5) Szórás \\
\hline K_A4 & 3015,71 & 20,73 & 255,78 & 2,31 \\
\hline K_A6 & 2803,01 & 0,00 & 360,25 & 0,00 \\
\hline K_C6 & 2224,21 & 20,61 & 172,32 & 1,82 \\
\hline K_A7 & 3335,29 & 37,77 & 188,89 & 2,54 \\
\hline A_A4 & 3069,74 & 19,10 & 183,99 & 2,03 \\
\hline A_C4 & 2828,12 & 35,76 & 198,00 & \\
\hline
\end{tabular}


Az OTU-k közül 3242 csak a kukorica felszíni talajmintákban (K_Ax), 2155 csak az abszolút kontroll talajmintákban (A_x4), 916 csak a kukorica mélységi talajmintában (K_C6), 770 csak a mélységi kontroll talajmintában (A_C4), 1812 csak a C szintből származó talajmintákban (xC_y), míg 4823 csak az A szintből származó talajmintákban (x_Ay) volt jelen.

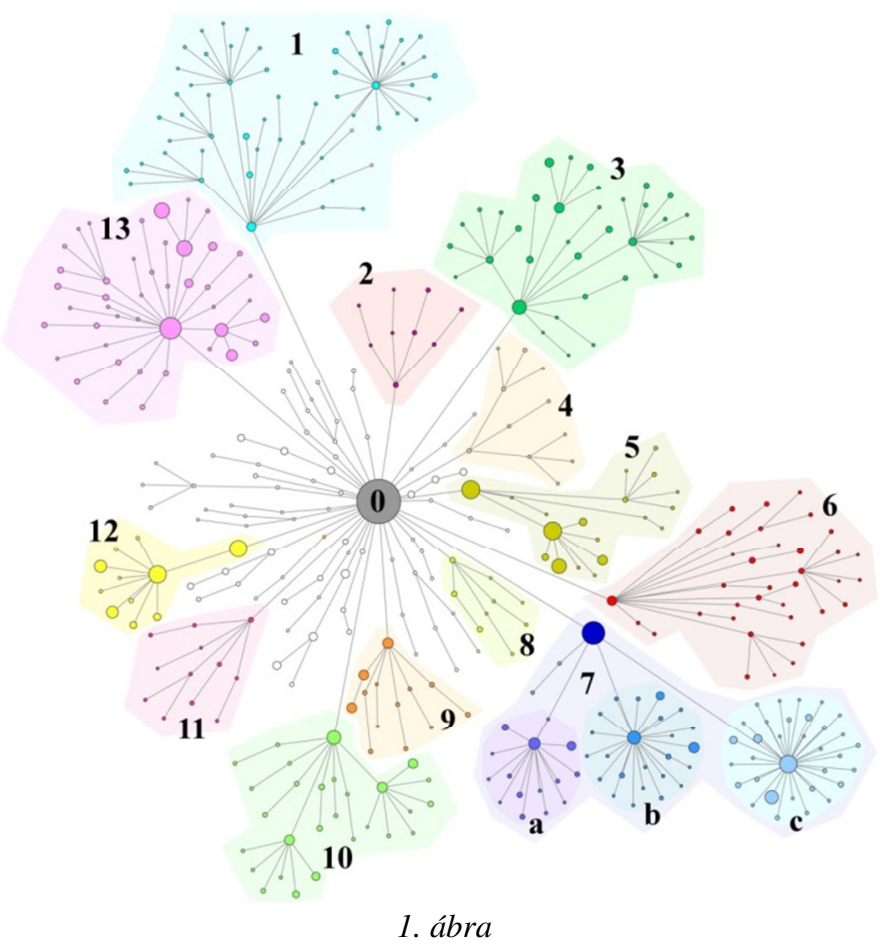

A vizsgálatba vont talajminták teljes halmazában azonosított OTU-k abundanciája alapján rajzolt hálózat.A végpontokon a rendek láthatók. A körök mérete az adott taxon abundanciájának négyzetgyökével arányos.

0: Bacteria. A színezéssel kiemelt törzsek: 1: Patescibacteria; 2: Armatimonadetes; 3: Actinobacteria; 4: Cyanobacteria; 5: Bacteroidetes; 6: Chloroflexi; 7: Proteobacteria [a: $\delta$-Proteobacteria; b: $\alpha$-Proteobacteria; $\mathbf{c}: \gamma$-Proteobacteria $] ; 8$ : Firmicutes; 9:

Gemmatimonadetes; 10: Planctomyces; 11: Elusimicrobia; 12: Verrucomicrobia; 13: Acidobacteria

A szekvenálás során a minták teljes halmazában azonosított OTU-k alapján rajzolt Cytoscape hálózaton (1. ábra) a törzsek, osztályok, rendek száma és abundanciája látható. A körök mérete az adott taxon abundanciájának négyzetgyökével arányos; a 34 törzs közül a legnagyobb diverzitást és abundanciát (A) mutató 13 törzset (Patescibacteria [A = 2,29\%], Armatimonadetes [A = 0,32\%], Actinobacteria $[\mathrm{A}=7,55 \%]$, Cyanobacteria $[\mathrm{A}=0,12 \%]$, Bacteroidetes [A = 13,69\%], Chloroflexi [A = 2,69\%], Proteobacteria $[\mathrm{A}=23,56 \%]$, Firmicutes $[\mathrm{A}=0,39 \%]$, Gemmatimonadetes $[\mathrm{A}=3,50 \%]$, Planctomyces $[\mathrm{A}=7,19 \%]$, 
Elusimicrobia $[\mathrm{A}=0,29 \%$, Verrucomicrobia $[\mathrm{A}=12,58 \%]$, Acidobacteria [A = 20,36\%]) különböző színekkel kiemeltük.

$\mathrm{Az}$ adatok részben alátámasztják a szakirodalomban említett taxonok jelentőségét (PEIFFER et al., 2013; GARCía-SALAMANCA et al., 2013; Li et al., 2014/I; LI et al., 2014/II; JOHNSTON-MONJE és RAIZADA, 2011), hiszen az általunk vizsgált talajmintákban a Bacteroidetes és Actinobacteria törzsek, valamint a $\gamma$-Proteobacteria osztály képviselői egyaránt nagy abundanciával voltak jelen. A Proteobacteria és az Actinobacteria kukorica rizoszféra talajban mérhető taxonómiai sokfélesége (az adatok nem szerepelnek a cikkben) szintén egybevág a szakirodalmi adatokkal (LI et al., 2014/II). A Verrucomicrobia esetében a magas abundancia nem cseng egybe más kutatók eredményeivel, továbbá meglepő az Acidobacteria hangsúlyos jelenléte és nagy változatossága (PEIFFER et al., 2013). A Cyanobacteria és a Firmicutes alacsony képviseltsége szintén eltér a szakirodalomban említett eredményektől (LI et al., 2014/I).

Külön említést érdemel, hogy a Patescibacteria CPR (Candidate Phyla Radiation) taxon jelenléte egyes mintákban $4 \%$ fölötti volt; a feltételezett (de ezidáig tenyésztésbe nem vont) rendszertani egység alá tartozó taxonómiai diverzitás igen nagy volt, ugyanakkor erről a szupertörzsről még nagyon kevés információ áll rendelkezésre (BROWN et al., 2015; SCHULZ et al., 2017). Egyes feltételezések szerint a Bacteria törzsfa ágainak mintegy 25\%-a Patescibacteria szupertörzshöz tartozhat (SCHULZ et al., 2017), és a Bacteria domain 15\%-át is kitehetik az ide tartozó fajok (BROWN et al., 2015).

A 3. táblázat alapján a kukorica monokultúra felszíni talajában a vegetációs időszak során egyre kisebb arányban voltak jelen a Bacteroidetes törzs tagjai, míg a Gemmatimonadetes, az Actinobacteria és a Planctomyces abundanciája idővel növekedett. A kukorica monokultúra talajának C rétegében (K_C6) az A-hoz képest (K_A6) az Actinobacteria, az Acidobacteria és a Gemmatimonadetes jelenléte hangsúlyosabb volt, míg a Verrucomicrobia, a Proteobacteria, a Planctomyces és a Bacteroidetes relatív abundanciája kisebb volt; a C rétegben $20 \%$ fölötti arányban jelentek meg egyéb törzsek. Az A_C4 mintában feltünően alacsony volt az Acidobacteria törzs abundanciája, míg a Bacteroidetes részesedése igen nagynak mutatkozott. A felszíni minták közt az A_A4-ben találtuk a Bacteroidetes és a Gemmatimonadetes legkisebb arányú képviseltségét, míg az Actinobacteria és a Planctomyces törzsekre nézve az abundancia magas volt.

$$
\text { 3. táblázat }
$$

A baktériumtörzsek relatív abundanciája az egyes talajmintákban

\begin{tabular}{lrrrrrr}
\hline (1) Baktérium törzsek & K_A4 & A_A4 & A_C4 & \multicolumn{1}{c}{ K_A6 } & \multicolumn{1}{c}{ K_C6 } & \multicolumn{1}{c}{ K_A7 } \\
\hline Acidobacteria & $23.09 \%$ & $20.55 \%$ & $14.72 \%$ & $18.09 \%$ & $21.42 \%$ & $24.19 \%$ \\
Actinobacteria & $2.30 \%$ & $8.47 \%$ & $7.37 \%$ & $6.15 \%$ & $14.06 \%$ & $6.21 \%$ \\
Bacteroidetes & $20.14 \%$ & $8.85 \%$ & $21.46 \%$ & $14.72 \%$ & $2.75 \%$ & $13.25 \%$ \\
Gemmatimonadetes & $2.80 \%$ & $1.68 \%$ & $1.37 \%$ & $3.19 \%$ & $7.70 \%$ & $4.08 \%$ \\
Planctomycetes & $5.38 \%$ & $11.76 \%$ & $6.75 \%$ & $6.88 \%$ & $5.03 \%$ & $7.73 \%$ \\
Proteobacteria & $24.32 \%$ & $23.44 \%$ & $24.89 \%$ & $26.54 \%$ & $20.18 \%$ & $23.04 \%$ \\
Verrucomicrobia & $13.00 \%$ & $14.26 \%$ & $15.89 \%$ & $12.20 \%$ & $5.30 \%$ & $14.14 \%$ \\
Egyéb (a) & $8.97 \%$ & $10.99 \%$ & $7.55 \%$ & $12.23 \%$ & $23.56 \%$ & $7.38 \%$ \\
\hline
\end{tabular}


A 9059 OTU-ból álló adatbázist Bray-Curtis féle hasonlóságon alapuló NMDS analízisnek vetettük alá (2. ábra). A két tengely mentén a kukorica felszíni rétegéből származó K_A4, K_A6, K_A7 egyértelmủen egy csoportba rendeződött, azaz ezek a minták nagy arányban osztoztak baktériumközösségeik összetételében. A kontroll gyep alól származó A_A4 és A_C4 szintén összetartott, és elkülönültek a művelt területektől. A K_C6 mindkét csoporttól élesen elvált; a K_Ax és a K_C6 közötti különbség sokkal kifejezettebb volt, mint az A_A4 és az A_C4 közti eltérés.

A Bray-Curtis hasonlóságra épülő SIMPER-teszt alapján az általunk vizsgált mintákban az NMDS kétdimenziós vetületének kialakulására egy tenyésztésbe nem vont Burkholderiaceae [Proteobacteria] nemzetség, az RB41 Pyrinomonadaceae [Acidobacteria] nemzetség és a 0319-7L14 [Actinobacteria] nemzetség gyakorolt 1\%-nál nagyobb hatást. A SIMPER-teszt alapján a 0,5\%-nál nagyobb varianciát okozó taxonok között Rokubacteriales [Rukobacteria], Chitinophagaceae [Bacteroidetes], Pedospheraceae [Verrucomicrobia], Sphingomonas [Proteobacteria], Acidibacter [Proteobacteria], Luteolibacter [Verrucomicrobia], Chthoniobacter [Verrucomicrobia], Flavobacterium [Bacteroidetes] és MNDI [Proteobacteria] taxonok voltak jelen.

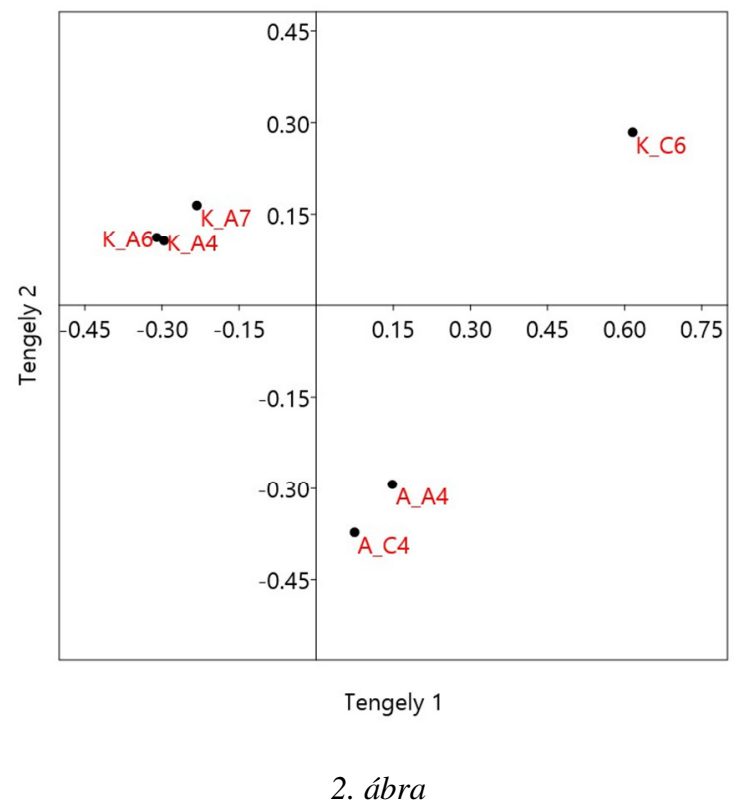

A 9059 OTU előfordulása alapján végzett Bray-Curtis féle NMDS két dimenziós vetülete

A SIMPER-teszt alapján a kukorica felszíni talaja (K_A4, K_A6, K_A7) a kontrolltól (A_A4) eltért egyes karakterisztikus Sphingomonadales, Betaproteobacteriales, Chitinophagales, Pyrinomonadales, Blastocatellales, Subgroup 6 rend, Rocubacteriales, Chthoniobacterales, Pedosphaerales és Xanthomonadales nemzetségek jelenlétében. A K_A6 és a K_C6 összehasonlítása 
során a varianciát Pyrinomonadales, 0319-7L14 rend, Betaproteobacteriales, Rokubacteriales, Nitrospirales, Chthoniobacterales és GAL 15 rendbe tartozó nemzetségek okozták.

A Flavobacteriales (Bacteroidetes) és az RB41 (Acidobacteria) tagjait antropogén hatásoknak kitett területeken megnövekedett abundanciával írták le (GUPTA et al., 2017); a martonvásári minták alapján ezt nem tudtuk egyértelmúen igazolni - bár az RB41 nemzetségnek 7 OTU-ja is elérte a 100-as szekvenciaszámot legalább egy mintában. $\mathrm{Az} R B 41$ folyamatos múvelés alatt álló területek (pl. gyapotföldek) esetében a legelterjedtebb Acidobacteria nemzetség is lehet (QIAO et al., 2017); eredményeink ezt alátámasztják. A legnagyobb varianciát okozó $R B 41$ OTU a C rétegben alig volt jelen, míg az A_A4-ben kis számban volt megtalálható a kukorica monokultúra felszíni mintáihoz képest (K_Ax). A Flavobacterium nemzetség foszfátmobilizáló hatása jól ismert (SHARMA et al., 2013; BHARDWAJ et al., 2014), így jelenléte hatással lehet a termesztett növény növekedésére. Mindemellett a Flavobacterium fajok biocid vegyületek (pl. herbicidekben, inszekticidekben, fungicidekben és molluszkicidekben egykor használt penta-kloro-fenol) degradációjára is képesek (SABER és CRAWFORD, 1985), tehát a növénytermesztés szempontjából jelenlétük előnyös lehetne. Ennek ellenére az A_C4-ben detektáltuk a legmagasabb Flavobacteriales abundanciát $(3,882 \%)$.

A 0319-7L14 jelzésủ Actinobacteria rend a feozjomok és a barna erdőtalajok egyik jellemző baktériumcsoportja (PERSHINA et al., 2018); mintáink közül kizárólag a K_C6-ban volt jelen, de a terület talajtani jellegéből és történetéből adódóan a taxon jelenléte nem meglepö.

A Burkholderiaceae család (Proteobacteria) igen diverz taxonokat foglal magába, metabolikus útvonalaik változatosak; több izolált törzsről is leírtak PGPB, biokontroll, vagy bioremediációs potenciált (COENYE és VANDAMME, 2003). A taxon széleskörü elterjedésének egyik kulcsa lehet a gombákkal való kölcsönhatás, mely lehetővé teszi a Burkholderiaceae megjelenését szuboptimális környezetekben is (STOPNISEK et al., 2016). Az NGS eredményei alapján a 4 legnagyobb abundanciát mutató Burkholderiaceae OTU mind a hat általunk vizsgált mintában jelen volt. A legnagyobb varianciát $(1,284 \%)$ okozó OTU viszont a K_C6 mintában nem volt jelen, míg az A_A4 mintában 1320 kópiában találtuk meg a taxonhoz rendelhető 16S rRNS gén szekvenciát. A Massilia nemzetség (Proteobacteria) jellemző a kukorica rizoszférájára (LI et al., 2014/II); adatbázisunkban a legnagyobb abundanciát mutató OTU szinte kizárólag csak a kukorica felszíni talajmintákban fordult elő (K_Ax).

Az ammónia-oxidáló MND1 nemzetség (Proteobacteria) megnövekedett abundanciáját kukorica és köles alól származó talaj esetében már leírták (HARGREAVES et al., 2015), de az MND1 a feltételezések szerint igen széles elterjedésủ taxon (SPAIN et al., 2009). A szekvenálás során a nemzetség 3 OTU-ját találtuk 100 szekvencia fölött legalább egy mintában; mindhárom OTU a kukorica monokultúrára volt jellemző - kettő közülük a C rétegre (K_C6).

A Sphingomonas nemzetséggel (Proteobacteria) kapcsolatban megállapították, hogy az egyszikủ növények (így a kukorica) rizoszférájának jellemző tagja; a 
növény belső szöveteit is kolonizálhatja (HAICHAR et al., 2008; PEIFFER et al., 2013). A K_A7 felszíni kukorica monokultúra mintában 1086 kópiában találtunk meg egy Sphingomonas OTU-hoz tartozó szekvenciát; ez a taxon az összes többi mintában egyenletesen, 400 kópia körül volt jelen. Sphingomonas törzsekröl leírták a ma is széles körben használt, nehezen lebontható izoproturon herbicid mineralizálásának képességét is (MUDD et al., 1983; SøRENSEN et al., 2001; HUSSAIN et al., 2011).

A Verrucomicrobia törzs jelenléte fontos jellemzője füves területek, így a magasfüvű préri társulások talajának (FIERER et al., 2013). Jelen vizsgálatunk során ugyanakkor kevés a bicskei kontroll talajmintára (A_A4) jellemző taxont találtunk. A C-szinten kifejezettebbek voltak a különbségek a müvelt és a müveletlen területek Verrucomicrobia közösségei között. A Verrucomicrobia törzsbe tartozó Pedosphaerales rend képviselőit egy kutatás során a nagyobb méretü talajaggregátumok belsejében szignifikánsan nagy abundanciával találták meg (BACH et al., 2018). Az általunk vizsgált talajokban a hét legnagyobb abundanciát mutató Pedosphaeraceae OTU közül 5 nem volt jellemzö a $\mathrm{C}$ rétegre. A Luteolibacter nemzetség (Verrucomicrobia) tagjai között elöfordulnak rizoszféralakó, több növényi gazdához is köthető fajok (DA RoCHA et al., 2013), ugyanakkor a saját minták esetében csak az A_C4 tartalmazott jelentős számú 16S rRNS gén szekvenciát a taxonból. A Chthoniobacter (Verrucomicrobia) nemzetség tagjai közt nagy arányban találhatók talajlakó heterotróf baktériumok (BERGMANN et al., 2011); a Chthoniobacterales rendhez sorolható OTU-k közül 12 volt jelen 100-nál több kópiában legalább egy mintában. Ezek közül 6 nem, vagy alig volt jelen a K_C6 mintában, míg 1 OTU csak a K_C6-ra volt jellemző.

Összességében tehát a legelterjedtebb, illetve a minták közti variancia nagy hányadáért felelös taxonok jó részét korábban már leírták talajokból. Az általunk vizsgált mikrobaközösségek e karakterisztikus tagjai részben a kukorica, részben az egysziküek rizoszférájához köthetők; némelyek az antropogén hatásokról árulkodhatnak (mely mentén azonban nem vált el élesen a vizsgálatba vont kontroll terület a többitől).

A MicroResp ${ }^{\mathrm{TM}}$ szubsztrát-indukált légzési aktivitásmérés alapján megállapítottuk, hogy a természetes löszpusztagyep felszíni talajának (A_A4) aktivitása minden egyes szubsztrát esetében kiugró értéket mutatott a többihez képest (az adatok nem szerepelnek a cikkben). A vizsgált minták között minden esetben a kontroll terület mélyebb talajmintájának (A_C4) szubsztrát-indukált légzési aktivitása volt a legkisebb - a dihidroxi-benzoát kivételével. A legnagyobb hatékonysággal a trehalóz, a glükóz, a fruktóz, a maltóz, a szukcinát, az aszparagin és a szerin hasznosult a légzési aktivitás alapján. A legkevésbé az alanin, a lizin, az arginin, a szorbitol, a rhamnóz és a glükonát hasznosult, vagyis mindkét csoportban előfordultak cukrok, szerves savak és aminosavak is. 


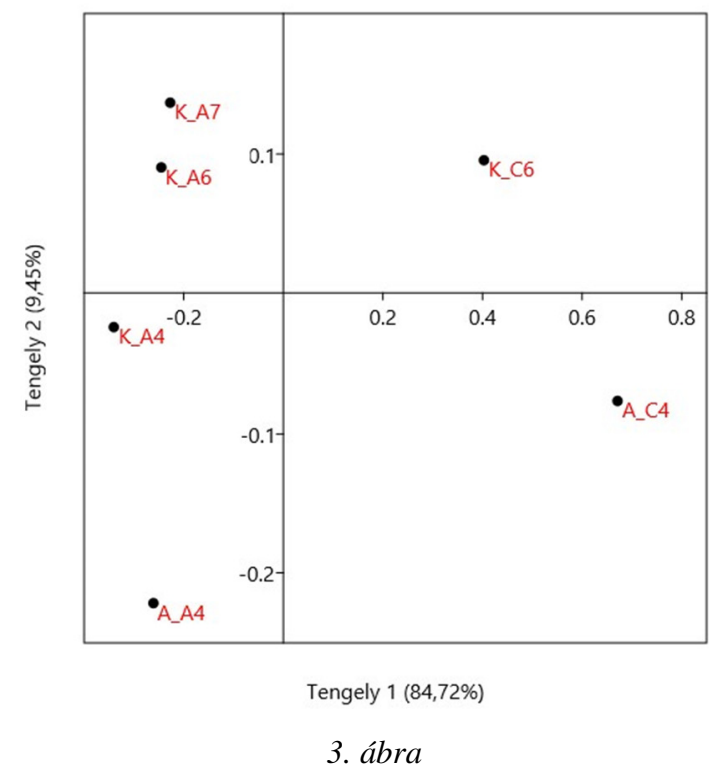

A MicroResp ${ }^{\mathrm{TM}} 23$ szubsztráttal végzett aktivitásmérés alapján végzett Euklideszi NMDS két dimenziós vetülete az egyes minták metabolikus potenciáljáról

A metabolikus potenciál adataival mintánkénti átlagra standardizálva és Euklideszi hasonlóságot használva szintén NMDS elemzést végeztünk (3. ábra). A két tengely 84,72\%-ban és 9,45\%-ban magyarázta a minták közti varianciát. A kukorica monokultúra felszíni talajmintái (K_Ax) együtt csoportosultak. Az élő kukorica alól vett K_A6 és K_A7 minták szorosan összetartottak. A C rétegből származó K_C6 és A_C4 minták a metabolikus potenciál tekintetében hasonlóságot mutattak. Ez azonban valószínűleg annak tudható be, hogy mindkét mintának rendkívül alacsony volt a respirációs aktivitása az összes szubsztrátra nézve, és ezért nem különülhettek el egymástól. Az A_A4 jelzésủ kontroll minta az NMDS alapján erőteljesen elvált a többitől; ez alapján kisebb hasonlóság mutatkozott az A rétegek talajai közt, mint a $\mathrm{C}$ réteg mintái közt. Az Euklideszi hasonlóságra támaszkodó SIMPER-teszt alapján a varianciára legerősebb befolyással bíró változók a dihidro-benzoát, a glükóz, a fruktóz, a maltóz, a trehalóz, a lizin, a xilóz, a szukróz, az arabinóz és az arginin voltak.

A különböző mủvelésủ talajok és talajrétegek a vizsgált metabolikus potenciál alapján NMDS számítással jól elkülöníthetők voltak egymástól. A C réteg mintáinak elválása a többitől erősen különböző környezet miatt várható volt.

\section{Következtetések}

Jelen kutatás egy a fenntartható talajerőforrás biztosítása érdekében folytatott átfogó kutatási projekt első állapotfelmérésének tekinthető, melyben kukorica monokultúrából és egy természet közeli löszpusztagyepből származó talajminták 
mikrobaközösségeit filogenetikai diverzitásuk és metabolikus potenciáljuk alapján hasonlítottuk össze.

Eredményeink arra mutattak rá, hogy az NGS vizsgálatok alapján a rizoszféra talajminták mind a művelési mód, mind pedig a talajmélység alapján különböztek egymástól, vagyis a mikrobaközösségek filogenetikai diverzitása alapján határozottan el lehetett különíteni egymástól a mezőgazdasági művelés alatt álló és a természeteshez közeli állapotú talajokat. A kukorica monokultúra esetében a mélyebb C talajrétegre jellemző mikrobaközösségek elkülönültek a szántott szint mintáitól.

A kukorica rizoszférájának baktériumközösségeit tárgyaló szakirodalomban meghatározónak tekintett taxonok jelenlétét csak részben sikerült igazolnunk. Ennek egyik oka az lehet, hogy a kutatás során relatíve kevés mintával dolgoztunk. Emellett a termőhelyi adottságok is hozzájárulhattak az eredmények különbözőségéhez (LI et al., 2014/II), valamint a kukorica genotípusa és a trágyázás módja (esetünkben a trágyázás hiánya) is befolyással lehetett az eredményeinkre. A baktériumközösségek PGPB tulajdonsággal rendelkező tagjainak vizsgálata kiemelkedő fontossággal bírhat a továbbiakban.

$\mathrm{Az}$ aktivitásvizsgálatok a szubsztrát típusától függetlenül a kontroll terület felszíni rétegének a többi mintához képest kiugró metabolikus potenciálját igazolták. A minta magas $\mathrm{CO}_{2}$-termelése a változatos növényfajokhoz tartozó és igen sürủ gyökérzet biztosította környezettel hozható összefüggésbe; a diverz flóra sokféle rizoexudátumot biztosít a talajlakó mikroorganizmusoknak, így sok niche alakul ki az adott környezetben, melyeket különböző adaptációs stratégiákkal rendelkező mikrobák tölthetnek be.

A vizsgálati eredményekből a fenntartható mezőgazdasági müvelésre vonatkozó általános következtetések kialakításához azonban még további részletes kutatások szükségesek.

\section{Összefoglalás}

E tanulmány célja egy martonvásári hosszútávú tartamkísérlet trágyázás nélkül művelt kukorica monokultúra talajában fellelhető baktériumközösségek filogenetikai diverzitásának és anyagcsere potenciáljának a felmérése volt. A kutatás során NGS és MicroResp ${ }^{\mathrm{TM}}$ technikával vizsgáltuk a müvelt és a természeteshez közeli állapotú talajok mikrobiális jellemzőit.

Az NGS adatai alapján a kukorica monokultúra szántott rétegének mintáinak baktériumközösség szerkezete nagyfokú hasonlóságot mutatott egymással, és elkülönült a löszpusztagyep A és C rétegéből formálódó csoporttól, míg a kukorica monokultúra $\mathrm{C}$ szintjéből származó minta élesen elvált a többitől. A gyepek talajában nem találtunk nagyobb bakteriális taxonómiai diverzitást, mint a müvelt talajokban.

A MicroResp ${ }^{\mathrm{TM}}$ mérés alapján megállapítottuk, hogy a természeteshez közeli állapotú talajok felszínhez közeli (A) rétegében kiugró a mikrobiális aktivitás mértéke. A kukorica monokultúrából származó A szint minták mikrobiális aktivitási 
mintázata egymáshoz hasonló volt, a C rétegből származó minták külön csoportot képeztek.

Eredményeink alapján tehát a hosszú távú tartamkísérletbe vont mủvelt talajok baktériumközösségeinek filogenetikai diverzitása és metabolikus potenciálja jelentősen eltért a löszpusztagyep mintákétól.

Kulcsszavak: baktériumközösség, diverzitás, kukorica, légzési aktivitás, rizoszféra

\section{Köszönetnyilvánítás}

Köszönettel tartozunk Dr. ÁRENDÁs Tamásnak a mintavételek tervezésében és kivitelezésében nyújtott segítségéért, Dr. SZALAI Zoltánnak és Dr. JAKAB Gergelynek a mintavételek során nyújtott segítségért, Dr. KALAPOS Tibornak a cönológiai felvételezésért, valamint DR. SzILI-KovÁCS Tibornak a MicroResp mérésekben végzett útmutatásért. A kutatás finanszírozása a GINOP-2.3.2-15-201600056 azonosítójú projekt költségvetéséből történt.

\section{Irodalom}

Aira M., Gómez-Brandón M., LazCano C., BÅÅTh E., Domínguez J. (2010) Plant genotype strongly modifies the structure and growth of maize rhizosphere microbial communities. Soil Biology \& Biochemistry 42. (12) 2276-2281

Bach E. M., Williams R. J., Hargreaves S. K., Yang F., Hofmockel K. S. (2018) Greatest soil microbial diversity found in micro-habitats. Soil Biology \& Biochemistry 118. 217-226

BAUDOIN E., BENIZRI E., GUCKERT A. (2003) Impact of artificial root exudates on the bacterial community structure in bulk soil and maize rhizosphere. Soil Biology \& Biochemistry 35. (9) 1183-1192

BerG G., SMALla K. (2009) Plant species and soil type cooperativelyshape the structure and function of microbial communities in the rhizosphere. [review] FEMS Microbiology Ecology 68. (1) 1-13

Bergmann G. T., Bates S. T., Eilers K. G., Lauber C. L., CAporaso J. G., Walters W. A., KNight R., Fierer N. (2011) The under-recognized dominance of Verrucomicrobia in soil bacterial communities. Soil Biology \& Biochemistry 43. (7) 1450-1455

BERZSENYI Z. (2010) Significance of the 50-year-old long-term experiments in Martonvásár in improving crop production. Acta Agronomica Hungarica 58. 2334

Bhardwaj D., Ansari M. W., Sahoo R. K., Tuteja N. (2014) Biofertilizers function as key player in sustainable agriculture by improving soil fertility, plant tolerance and crop productivity. [review] Microbial Cell Factories 13. 66

Brown C. T., Hug L. A., Thomas B. C., Sharon I., Castelle C. J., Singh A., Wilkins M. J., Wrighton K. C., Williams K. H., BANField J. F. (2015) Unusual biology across a group comprising more than $15 \%$ of domain Bacteria. Science 523. (7559) 208-211 
CAmpbell C. D., Chapman S. J., Cameron C. M., Davidson M. S., PotTs J. M. (2003) A rapid microtiter plate method to measure carbon dioxide evolved from carbon substrate amendments so as to determine the physiological profiles of soil microbial communities by using whole soil. Applied and Environmental Microbiology 69. (6) 3593-3599

CoEnYe T., VAndamme P. (2003) Diversity and significance of Burkholderia species occupying diverse ecological niches. [review] Environmental Microbiology 5. (9) 719-729

Da Rocha U. N., PlugGe C. M., George I., van Elsas J. D., van Overbeek L. S. (2013) The rhizosphere selects for particular groups of Acidobacteria and Verrucomicrobia. PLoS ONE 8. (12) 16-20 [e82443]

Fierer N., Ladau J., Clemente J. C., LefF J. W:, Owens S. M., Pollard K. S., Knight R., Gilbert J. A., McCulley R. L. (2013) Reconstructing the microbial diversity and function of pre-agricultural tallgrass prairie soils in the United States. Science 342. (6158) 621-624

Garbeva P., van Veen J. A., VAN Elsas J. D. (2003) Predominant Bacillus spp. in agricultural soil under different management regimes detected via PCRDGGE. Microbial Ecology 45. (3) 302-316

GARbeVA P., VAN VEen J. A., VAN Elsas J. D. (2004) Microbial diversity in soil: Selection of microbial populations by plant and soil type and implications for disease suppressiveness. [review] Annual Review of Phytopathology 42. (1) 243-270

García-Salamanca A., Molina-Henares M. A., van Dillewijn P., Solano J., Pizarro-Tobías P., Roca A., Duque E., Ramos J. L. (2013) Bacterial diversity in the rhizosphere of maize and the surrounding carbonate-rich bulk soil. Microbial Biotechnology 6. (1) 36-44

Gupta S., Kumar M., Kumar J., AhMad V., PANDey R., Chauhan N. S. (2017) Systemic analysis of soil microbiome deciphers anthropogenic influence on soil ecology and ecosystem functioning. International Journal of Environmental Science and Technology 14. (10) 2229-2238

haichar F. Z., Marol C., Berge O., Rangel-Castro J. I., Prosser J. I., BALesdent J., Heulin T., ACHOUAK W. (2008) Plant host habitat and root exudates shape soil bacterial community structure. The ISME Journal 2. (12) 1221-1230

Hargreaves S. K., Williams R. J., HofMOcKel K. S. (2015) Environmental filtering of microbial communities in agricultural soil shifts with crop growth. PLoS ONE 10. (7) 1-14 [e0134345]

Hartmann M., Frey B., MAYer J., MÄDER P., WidMer F. (2015) Distinct soil microbial diversity under long-term organic and conventional farming. The ISME Journal 9. (5) 1177-1194

Hayat R., Ali S., Amara U., Khalid R., Ahmed I. (2010) Soil beneficial bacteria and their role in plant growth promotion: a review. [review] Annals of Microbiology 60. (4) 579-598 
Hussain S., Devers-Lamrani M., Azhari N. E., Martin-Laurent F. (2011) Isolation and characterization of an isoproturon mineralizing Sphingomonas sp. strain SH from a French agricultural soil. Biodegradation 22. (3) 637-650

Ishaq S. L., Johnson S. P., Miller Z. J., Lehnhoff E. A., Olivo S., YeOMan C. J., MENALLED F. D. (2017) Impact of cropping system, soil inoculum, and plant species identity on soil bacterial community structure. Microbial Ecology 73. (2) 417-434

JENKINSON D. S. (1977) The soil biomass. NZ Soil News 25. 213-218

JOHNSTON-MONJE D., RAIZADA M. N. (2011) Conservation and diversity of seed associated endophytes in Zea across boundaries of evolution, ethnography and ecology. [review] PLoS ONE 6. (6) 1-22 [e20396]

KAndeler M., Marschner P., Tscherko D., GAHOOnia T. S., NiElsen N. E. (2002) Microbial community composition and functional diversity in the rhizosphere of maize. Plant and Soil 238. 301-312

Li X., Rui J., Xiong J., Li J., He Z., Zhou J., Yannarell A. C., Mackie R. I. (2014/I) Functional potential of soil microbial communities in the maize rhizosphere. PLoS ONE 9. (11) 1-9 [e112609]

Li X., Rui J., Mao Y., Yannarell A., Mackie R. (2014/II) Dynamics of the bacterial community structure in the rhizosphere of a maize cultivar. Soil Biology \& Biochemistry 68. 392-401

Ling N., Sun Y., MA J., GuO J., Zhu P., Peng C., Yu G., RAN W., GuO S., SheN Q. (2014) Response of the bacterial diversity and soil enzyme activity in particle-size fractions of Mollisol after different fertilization in a long-term experiment. Biology and Fertility of Soils 50. (6) 901-911

LundQuist E. J., ScOW K. M., JACKSON L. E., Uesugi S. L., JOHnson C. R. (1999) Rapid response of soil microbial communities from conventional, low input, and organic farming systems to a wet/dry cycle. Soil Biology \& Biochemistry 31. 1661-1675

Mucsi M., Csontos P., Borsodi A., Krett G., Gazdag O., Szili-Kovács T. (2017) A mikrorespirációs (MicroResp ${ }^{\mathrm{TM}}$ ) módszer alkalmazása apajpusztai szikes talajok mikrobaközösségeinek katabolikus aktivitás mintázatának vizsgálatára. Agrokémia és Talajtan 66. (1) 165-179

MudD P. J., HANCE R. J., WRIGHT S. J. L. (1983) The persistence and metabolism of isoproturon in soil. Weed Research 23. (5) 239-246

Pascual J. A., Garcia C., Hernandez T., Moreno J. L., Ros M. (2000) Soil microbial activity as a biomarker of degradation and remediation processes. Soil Biology \& Biochemistry 32. 1877-1883

Peiffer J. A., Spor A., Koren O., Jin Z., Tringe S. G., DAngl J. L., BuCKLER E. S., LEY R. E. (2013) Diversity and heritability of the maize rhizosphere microbiome under field conditions. PNAS 110. (16) 6543-6553

Pershina E. V., Ivanova E. A., Korvigo I. O., Chirak E. L., Sergaliev N. H., Abakumov E. V., Provorov N. A., Andronov E. E. (2018) Investigation of the core microbiome in main soil types from the East European plain. Science of the Total Environment 631-632. 1421-1430 
PÉreZ-Jaramillo J. E., Mendes R., RAaijmakers J. M. (2016) Impact of plant domestication on rhizosphere microbiome assembly and functions. [review] Plant Molecular Biology 90. (6) 635-644

Qiao Q., Wang F., Zhang J., Chen Y., Zhang C., LiU G., Zhang H., Ma C., ZHANG J. (2017) The variation in the rhizosphere microbiome of cotton with soil type, genotype and developmental stage. Nature Scientific Reports 7. 3940

SABER D. L., CRAWFORD R. L. (1985) Isolation and characterization of Flavobacterium strains that degrade pentachlorophenol. Applied and Environmental Microbiology 50. (6) 1512-1518

Schulz F., Eloe-Fadrosh E. A., Bowers R. M., Jarett J., Nielsen T., IVANOVA N. N., KYRPIDES N. C., WOYKE T. (2017) Towards a balanced view of the bacterial tree of life. Microbiome 5. (1) 140

Shannon P., Markiel A., Ozier O., Baliga N. S., Wang J. T., Ramage D., AMin N., Schwikowski B., IDEKER T. (2003) Cytoscape: A software environment for integrated models of biomolecular interaction networks. Genome Research 13. (11) 2498-2504

Sharma S. P., SAyYed R. Z., Trivedi M. H., Gobi T. A. (2013) Phosphate solubilizing microbes: Sustainable approach for managing phosphorus deficiency in agricultural soils. [review] SpringerPlus 2. 587

SøRENSEN S. R., RONEN Z., AAMAND J. (2001) Isolation from agricultural soil and characterization of a Sphingomonas sp. able to mineralize the phenylurea herbicide isoproturon. Applied and Environmental Microbiology 67. (12) 54035409

Spain A. M., Krumholz L. R., ElShahed M. S. (2009) Abundance, composition, diversity and novelty of soil Proteobacteria. The ISME Journal 3. (8) 992-1000

StopniseK N., ZüHlke D., CARlier A., BARberÁN A., Fierer N., Becher D., RIEDEL K., EBERL L., WEISSKOPF L. (2016) Molecular mechanisms underlying the close association between soil Burkholderia and fungi. The ISME Journal 10. (1) 253-264

SzILI-KovÁcs T. (2004) Szubsztrát indukált respiráció a talajban. [review] Agrokémia és Talajtan 53. (1-2) 195-214

SzIli-Kovács T., BÁrÁny Á., FüZY A., TAKÁcs T., Krett G., Kovács R., BorsoDI A. (2017) Mikrobiális anyagcsere aktivitás-mintázat és mikorrhiza gomba kolonizáció elemzése három szikes tó melletti talaj rizoszférában. Agrokémia és Talajtan 66. (1) 149-164

VAN Elsas J. D., GarbeVA P., SAlles J. (2002) Effect of agronomical measures on the microbial diversity of soil as related to the suppression of soilborne plant pathogens. Biodegradation 13. 29-40

WidMer F., RASCHE F., HARTMANN M., Fliessbach A. (2006) Community structures and substrate utilization of bacteria in soils from organic and conventional farming systems of the DOK long-term field experiment. Applied Soil Ecology 33. (3) 294-307 
Mikrobaközösségek metabolikus aktivitása és ... filogenetikai diverzitása ...

\title{
Metabolic activity and 16S rRNA gene based phylogenetic diversity of soil bacterial communities in maize monoculture rhizosphere
}

\author{
Gergely UJVÁRI ${ }^{1}$, Andrea Borsodi ${ }^{1}$, Júlia AsZALÓs ${ }^{1}$, Melinda MEgYes ${ }^{1}$, \\ Márton MuCSI $^{2}$, Attila SzABÓ ${ }^{1}$, Károly MáRIALIGETI ${ }^{1}$ \\ ${ }^{1}$ Department of Microbiology, Eötvös Loránd University (ELTE), Budapest \\ ${ }^{2}$ Institute for Soil Sciences and Agricultural Chemistry, Centre for Agricultural \\ Research, Hungarian Academy of Sciences (MTA), Budapest
}

The main aim of this study was to survey the genetic diversity and metabolic potential of soil bacterial communities of an unfertilized maize monoculture maintained in a long-term field experiment in Martonvásár, Hungary. During the research work, NGS and MicroResp ${ }^{\mathrm{TM}}$ techniques were used to study the microbial communities of one cultivated and one close-to-nature area.

Based on the NGS results, the bacterial communities in samples taken from the tilled layer of the maize monoculture all clustered together, and were clearly separated from the group containing layers $\mathrm{A}$ and $\mathrm{C}$ of the control soil, while the sample from layer $\mathrm{C}$ of the maize monoculture diverged from all the others. The bacterial taxonomic diversity in the soils of the control area was no higher than in the cultivated soils.

According to the MicroResp ${ }^{\mathrm{TM}}$ measurement, layer A of close-to-nature soils showed an outstanding extent of microbial activity. Samples from layer A of the maize monoculture showed a similar pattern of microbial activity, while layer $\mathrm{C}$ samples composed a distinct group.

The results, thus indicated that the genetic diversity and metabolic potential of bacterial communities of cultivated soils included in this long-term field experiment differed greatly from those of close-to-nature samples.

Keywords: bacterial community, diversity, maize, respiratory activity, rhizosphere

\section{Tables and figures}

Table 1. Soil samples used in the experiment. (1) Sample code. (2) Land use. a) Grassland/Natural vegetation; b) Cropland/Maize monoculture. (3) Sampling location, $\mathrm{M}=$ Martonvásár, $\mathrm{B}=$ Bicske. (4) Sampling depth $[\mathrm{cm}]$. (5) Sampling date. a) April; b) June; c) July.

Table 2. Estimation of Chaol OTU-value and inverse Simpson diversity indices calculated from NGS. (1) Sample code. (2) Chaol OTU values. (3) Inverse Simpson index. (4) Mean. (5) Standard deviation. OTU = Operational taxonomic unit, NGS = next generation sequencing.

Table 3. Relative abundance of bacterial phyla in the individual soil samples. (1) Bacteria phyla. a) Others. 
Figure 1. Graphical network based on the abundance of OTUs identified in the whole sample set. Numbers represent bacterial orders. Circle size is proportional to the square root of the abundance of the given taxon. (0) Bacteria. The highlighted bacteria phyla are: (1) Patescibacteria. (2) Armatimonadetes. (3) Actinobacteria. (4) Cyanobacteria. (5) Bacteroidetes. (6) Chloroflexi. (7) Proteobacteria [a: $\delta$-Proteobacteria. b: $\alpha$-Proteobacteria. c: $\gamma$ Proteobacteria]. (8) Firmicutes. (9) Gemmatimonadetes. (10) Planctomyces. (11) Elusimicrobia. (12) Verrucomicrobia. (13) Acidobacteria.

Figure 2. NMDS (Non-metric multidimensional scaling) of the 9059 OTUs according to Bray-Curtis distance among the soil samples. Tengely $1=$ Axis 1 , Tengely 2 = Axis 2 .

Figure 3: NMDS of the 23 measured substrates according to the Euclidean similarity index among the soil samples. Tengely $1=$ Axis 1 , Tengely $2=$ Axis 2. 